${ }^{1}$ Ілля Литвичнук, ${ }^{2}$ Олег Рибчинський, ${ }^{1}$ аспірант кафедри архітектури та реставраџії email: illia.v.lytvynchuk@lpnu.ua

ORCID: 0000-0001-6908-532X

${ }^{2}$ професор кафедри архітектури та реставраиіi email: zoroleh@gmail.com ORCID: 0000-0001-9936-6122 Інститут архітектури та дизайну Національний університет «Львівська Політехніка»

\title{
PROBLEMS OF RESEARCH OF URBAN DEFENSE COMPLEXES OF CITIES OF THE EASTERN PODOLIA IN THE $16^{\text {th }}-18^{\text {th }}$ CENTURIES.
}

\author{
ПРОБЛЕМИ ДОСЛІДЖЕННЯ УРБАНІСТИЧНИХ ОБОРОННИХ \\ КОМПЛЕКСІВ МІСТ СХІДНОГО ПОДІЛЛЯ XVI-XVII СТ.
}

\author{
(C) Литвинчук I., Рибчинський, О., 2020
}

Анотація: У статті автори торкаються способів фортифікацій міст Східного Поділля. Складові довготривалих міських фортифікацій розглядаються як боина система так званих урбаністичних оборонних комплексів. Обов'язкові складові цієї системи - оборонний замок і укріплення середмістя, які фіксуються на картах військових картографів XVII-XVIII cm. Взявщи це до уваги, автори з'ясовують у статті стратегічне значення Східного Поділля для держави та розглядають розвиток урбаністичних оборонних комплексів на його території у ретроспективі.

На підставі натурних обстежень частково збережених урбаністиних оборонних комплексів у статті виділються основні типі в залежності від композиційно-планувальних та планувальних особливостей. 3 д допомогою можсливостей програмного забезпечення Google Earth проаналізувано також $\boldsymbol{i}$ розташування фортифікацій на рель'єфі. Співставлення данних перерізів рельєфу з перевіреними даними заснування укріплених населених пунктів виявило стійку кореляцію. Так, укріплення міст, щц були зановані у першій період (великокняэій), розташовувались на узвишші мисів, кряжів, пагорбів, тоді як укріплення пізніших розташовувались в долині. Враховуючи низький рівень дослідженості украӥнських міст на предмет аналізу ӥхніх оборонних комплексів, автори рекомендують у подальших дослідженнях детально дослідити групи міст, що складали маєткові комплекси конкретних магнатських родів на Поділлі - Каліновських, Збаразьких, Замойських, та інших на предмет наявності в них сдиної системи оборони території та виокремлення характерних особливостей об’ємно-планувальної композиції.

Ключові слова: Східне Поділля, Брацлавське восводство, урбаністичні оборонні комплекси, замки, міські укріплення, укріплення передмість. 


\section{Актуальність:}

Наявність оборонних укріплень традиційно вважається однією 3 головних відмінностей міських поселень від сільських. Проте, у дослідженнях українських вчених, тема фортифікацій хоч і проходить вздовж проблематики урбаністичного розвитку, але не розкривається у вигляді самодостатніх досліджень у всьому своєму комплексному різноманітті. Предметами досліджень у різних галузях (історія, географія, археологія, архітектура, містобудування, мистецтво) часто виступають лише окремі складові оборонних комплексів, зокрема, замки, інкастельовані сакральні, громадські чи житлові споруди, міські брами, тощо. Питанням впливу оборонних споруд на планувально-просторову композицію міста не приділено достатньої уваги, через що у науковому полі залишаються відкритими питання ідентифікації реліктів втрачених оборонних комплексів та методики їхніх досліджень. Через брак уявлення про урбаністичний оборонний комплекс у структурі давнього міста виникає і інша практична проблема: неможливість достовірно відтворити етапи розбудови міста, окреслити історичні ареали та запропонувати ревіталізації історичних міст України та їхню промоцію у програмах регіонального розвитку та туризму.

\section{Мета:}

Окреслити стан наукової розробки теми урбаністичних оборонних комплексів Східного Поділля XVI-XVIII століть, визначити їхнє функціональне призначення та характеристики.

\section{Аналіз попередніх досліджень:}

Як вже зазначалось, в українській науці відсутні праці з всеохоплюючим вивченням урбаністичних оборонних комплексів Східного Поділля. Лише окремим містам регіону присвячені публікації за темами, дотичними темі даного дослідження, а саме: Вінниці (Білінський, 1926; Отамановський, 1946), Брацлаві (Ричков, 2016), Сокільці (Кучера, 1965), Стіні (Пламеницька, 1990), Буші (Винокур), сукупність яких не дає можливість скласти репрезентативну типологію навіть окремих оборонних споруд для регіону. У 2017 р. авторами було опубліковано результати вперше проведених комплексних історикомістобудівних досліджень с. Рашків Кам'янського рацонку Придністров'я (кол. Брацлавського воєводства), де розглядались оборонні споруди міста у єдиному комплексі.

Найбільш часто дослідники системи укріплень українського прикордоння вживають аморфні, занадто загальні терміни «укріплене поселення», «оборонні укріплення міст» (Мальченко, 2001; Михайловський, 2002, Нагнибіда, 2008), що викликає резонне питання, на який саме компонент оборони міста скерована увага дослідника - на замки, міські укріплення чи на їхню сукупність у єдиний системі? Олег Мальченко уперше присвятив темі прикордонних укріплень окреме дослідження, опрацювавші джерела 3 історії Київського, Подільського та Брацлавського воєводств (згад. праця).

Найбільш широко у працях на фортифікаційну тематику представлено дослідження замків, як окремого об'єкту дослідження (Czolowski, Rolle, Логвин; Мацюк; Нельговський; Оконченко). Тема міських укріплень у науковому просторі менш популярна, ніж замкова. На сьогодняшній момент в Україні відносно досліджені міські укріплення Києва (Філіпова, 2016), Жовкви (Оконченко, Бевз, 2014), Чернігова (Бондар, 2017), Калуша (Федунків; Лукомська, Малишко, 2015), Івано-Франківська (Лукомська, 2017), Львова (Качор, Вуйцик, Могитич), Белза (Бевз; Бойко і Слободян), Луцька (Терський). 


\section{Виклад основного матеріалу. Поняття урбанстичного оборонного комплексу.}

Фортифікаційні споруди давніх міст утворювали єдину систему оборони, на що звертали увагу тогочасні картографи та військові інженери, зокрема, Г.Л. Боплан (1990), Й Янсоній (Кисілевський, 1966), Фюрстенхофф (Fürstenhoff, 1740) Р. Заноні (Кордт, 1931) та інші. Оборону міст вони вбачали у наявності двох обов'язкових компонентів - замку та укріпленого середмістя і третього - додаткового - укріпленого (их) передмістя(ь).

Під замком ми розуміємо невелику оборонну споруду, яка належала місцевому феодалу та мала би виконувати функції резиденції та адміністрування маєтку. Зауважимо, що існує кілька дефініцій поняття «замок» у науковій літературі і переважно всі вони стосуються резиденційних функцій споруди. Детально проблематику термінології дослідила О. Оконченко (2012). Проте, у нашому випадку ми будемо радше мати справу з замками, як невеликими фортецями, призначеними для зберігання майна та охорону панських намісників чи адміністраторів. Наприклад, родині Замойських від початку XVII ст. на Поділлі належали величезні латифундії з містами Шаргород, Чернівці, Стіна, Рашків, Кам’янка, Томашпіль, Буша, Яруга, Комаргород, Ямпіль, Красне, проте історії невідомі факти перебування їх у своїх східних маєтках. Павло Алепський називає такі замки «фортецями», а Е. Челебі «цитаделями». У інвентарі Рашкова 1661 p. (Tarnawski, 1935) наведено опис замкової артилерії, яка складалась 3 чотирьох гармат, натомість, нічого не сказано про озброєння укріплень міста на той момент, теж саме зустрічаємо і в інвентарі Вінниці 1604 p.

Міські укріплення оточували безпосередньо середмістя, яке у XVI-XVII ст. було невеликим і включало в себе ринкову площу з примикаючими кварталами щільної міської забудови. С. Кравцов зазначає, що оборонний периметр - це один з двох елементів плану, які визначали міський характер поселень (іншим була ринкова площа), з чим погоджується О. Рибчинський . (2017, с. 58), даючи дефініцію середмістя: це - «поліфункціональний, архітектурно-містобудівельний комплекс, сформований впродовж XIV - початку XX століть, з ядром - ринковою площею та периметром оборонних споруд. У люстраціях українських прикордонних замків 1545 (Кравченко, 2005) та 1552 (АрЮЗР, 1886) років опис міських укріплень йде в розділі повинностей міщан, до обов'язків яких входила оборона міста, або «сторожа». Сторожі поділялись на замкову, острогову, та польну, відповідно, міські укріплення звалися «острогом» і складалися з загостреного частоколу та брам. Крім частоколів у описах зустрічаються також і валово-ровові міські укріплення. Гваньїні (2007) описує Вінницю 1582 р. так: «Вінниця - місто дерев’яне, разом з замком валом оточене». Різноманітним типам міських укріплень приділяє увагу У. фон Вердум (Liske, 1876) - в своїх описах він розрізняє частоколи, вали з палісадами, також в його текстах часто зустрічається поняття міських укріплень «козацього типу». Найбільш повно міські укріплення описує П. Алепський (1897), зазначаючи що міста оточувались кількома рядами міських укріплень дерев'яних «стін». Втім, не дуже зрозуміло, чи йдеться про повноцінні фортифікаційні споруди чи звичайні паркани.

Укріплення передмість є явищем рідкісним для Брацлавщини, де міста через постійну небезпеку з боку татар не сягали такого рівня економічного розвитку, як у сусідніх Подільському чи Волинському воєводстві. Тем не менш, укріплення передмість зустрічаються у II пол. XVII у Красному, Буші, Рашкові, Брацлаві, Збаражі (Новому), Мурафі. Укріпленні передмістя брацлавських міст потребує додаткових досліджень внаслідок браку джерел, введених у науковий обіг під час публікації даної статті. 


\section{Географічне розташування та стратегічне значення Східного Поділля}

Особливості формування та адміністративно-політичного устрою цього регіону грунтовно досліджує М. Крикун (2015) від моменту утворення на його території Брацлавського воєводства у 1556 році. Зупинимось на основних відмінностях цього воєводства від інших, які, на нашу думку, вплинули на формування урбаністичних оборонних комплексів та їхню типологію в межах регіону. По-перше, це воєводство було виключно приватновласницьким. Лише два міста були королівськими, i, водночас, воєводськими - Брацлав і Вінниця. Вони були центрами однойменних невеличких староств, що складались 3 довколишніх сіл. Відповідно, держава не мала прямого впливу на стратегічну оборону регіону, перерозподіляючи свої обов'язки серед магнатів, які, у свою чергу, мали би бути матеріально зацікавленими у питанні оборони своїх вотчин. Не будемо забувати, що велике значення охорони південного кордону приділялось «польній» сторожі, а також «кварцяному» війську (створеному у 1562 р.), що не має відношення до довготривалих фортифікацій міського типу.

Друга особливість полягала у відсутності демаркації південного кордону не тільки Брацлавського воєводства, але усієї держави. Від Великого Князівства Литовського, за часи розквіту його руська колонізація сягнула узбережжя Чорного моря. Річ Посполита успадкувала претензії на ці землі навіть після того, як вони були втрачені внаслідок занепаду ВКЛ та наступу кочівників на північ (Добролюбський, 2011, с. 98-118). Найбільш висунуті на південь у степ поселеннями Речи Посполитої були Рашків, Чечельник, Нове Конєцполє, Умань, Кодак. Спірним залишався Ягорлик (Диба, Рязанова, 2019). Лише у 1699 р. південний кордон був демаркований і Ягорлик залишився за поляками. Князями Любомирськими на самому кордоні, навпроти татарського поселення Балти засновано містечко Юзефград (нині, разом з колишньою татарською Балтою - м. Балта Одеської області (Нагнибіда, 2018)).

Нарешті, третя особливість випливає 3 перших двох і полягає у відсутності адміністративно-територіального поділу, характерному для усієї території Речі Посполитої на повіти. Фактично, Брацлавське воєводство складалось з одного повіту, який називався інколи Брацлавським, інколи - Вінницьким, інколи - Вінницько-Брацлавським. Спроби налагодити адміністративно-повітовий устрій здійснювались у 1790-ті роки, напередодні II поділу Речі Посполитої, після якого територія Брацлавського воєводства перейшла до Російської Імперії і була долучена до новоствореної Подільської губернії. Територію воєводства у 1791 р пропонувалось поділити на чотири повіти: Брацлавський, Вінницький, Надбузький, Звенигородський (Volumina legum, 1889, с. 330-331).

В традиційній історіографії перевищується стратегічна цінність брацлавського воєводства для держави, напевно, з огляду на його прикордонне розташування. Дашкевич (1991) вважав його одним зі складових т. зв. «Великого кордону» зі степом. Натомість, через його території (крім татарських шляхів) проходив лише один важливий торгівельний шлях (т. зв. Брацлавський «гостинець») з Кам'янця до Києва через Брацлав (Гедзь 2010; Русов, 1889), який, однак, дублювався більш безпечним шляхом у Києвському воєводстві через Білу Церкву, уміцнену у сер. XVI ст. Торгівельні зв'язки «північ-південь» перервався завоюваням y II пол. XV ст. Османською імперією Константинополя та Криму з його генуезькими колоніями. Стратегічне значення мали хіба переправи через Дністер на Молдавію, які, однак, були належним чином захищені - Рашків, Ямпіль, Косниця. Натомість, в жодному з цих придністровських міст до II пол. XVIII ст. не було митниць. Усі важливі стратегічні пункти залишались довкола воєводства: Кам'янець, Бар, Біла Церква, Київ, Чигирин, Корсунь, Кодак, тобто, фактично, у Брацлавському воєводстві не було де закріпитися в умовах 
повномасштабної війни. Це доводять приклади військових кампаній XVII-I пол. XVIII ст. Так, після окупації Кам'янця турками, а Києва - московитами, Річ Посполита втратила контроль і над Брацлавським воєводством, на території якого було створено незалежну державу - гетьманат Дорошенка, пізніше - Сарматське Князівство Юрася Хмельницького. Цікавим є і те, що турки, окупувавши все Поділля, приєднали до своєї імперії лише його західну частину - Подільське воєводство, утворивши на його основі Кам'янецький еялет (детальніше про це у: Колодзейчик; Середа), тоді як східна частина (Брацлавщина) лишилась у напівнезалежному стані. $Є$ також іншій приклад - у 1711 р. гетьман Пилип Орлик захопив всю Брацлавщину і рушив на Білу Церкву, де зазнав поразки, після якої мусив відступити 3 України і позбутись усіх завоювань, тобто володіння Брацлавським воєводством йому не надало ніякої переваги у військовому плані.

Відсутність колонізаційного руху на південь у XVI-XVII ст. можна пояснити природнішими умовами - фактичний південний кордон воєводства співпадав з межею між лісостепом та степом, а як зазначав люстратор Кам'янецького староства в 1565 році, «...а люди на Русі не осідають ніде, як тільки біля води і лісу...» (Мальченко, 2001, с. 87).

Тем не менш, на території Брацлавського воєводства зустрічаються зразки потужних земляних бастіонових фортифікацій - у Рашкові, Пісочині, Верхівці, Кісниці, Коханові (можливо - і у інших недосліджених містах). Сам факт їхнього існування говорить про неабияке ставлення місцевої мегатерії до питання захисту своїх території. Спробуємо надати відповідь на питання функціонального призначення цих оборонних об'єктів, 3 яких формувались оборонні комплексі.

П. Алепський зазначає, що усі дороги України (i, зокрема, Брацлавщини), проходили через міста, оминути які було важко у ті часи, подорожуючи вершником чи на возах. $€$. Тичук (2016) зробив висновок, що обмеження у вільному просуванні на Поділлі було зумовлено рельєфом, які утворюють маленькі річки, що впадають у головні ріки воєводства - Дніпро, Південий Буг та Дністер. Яри та балки були недоланою перепоною до коней, відповідно, для контролю цієї території треба було мати фортеці на важливих кінних переправах - водних та судохольних. Утворюючи на них штучні перепони у вигляді фортець, можна було встановити опорні пункти для контролю транспортно-фінансових потоків та опорні пункти для оборони від набігів як кочівників, так і місцевих злодіїв, (а можливо i військових загонів приватної армії сусідів-магнатів). Контроль та безпека шляхів були не менш важливою турботою феодалів Брацлавщини, як і захист безпосередньо маєтків, адже через них до їхніх основних резиденцій, розташованих поза етнічними українськими землями, поступали грошові надходження, здійснювалась кореспонденція та взаємодія магната з місцевими адміністраторами.

\section{Стадійність формування урбаністичних оборонних комплексів.}

\section{Заміна державної стратегії оборони приватновласницькою.}

Через брак археологічних досліджень ми не маємо повної картини про залюдненість Східного Поділля у доординські часи, а першим літописним джерелом за цією темою (де, зокрема, згадуються Брацлав і Вінниця) $є$ «список руських міст» (А се имена всьм градом Рускым, далним и ближним // Новгородская первая летопись старшего и младшего изводов. - Москва-Ленинград, 1950, С. 475-477), де подільська група міст названа «польські міста» (сам «список» датується останньою третиною XIV ст.). Достовірно відомо хіба про південні кордоні Галицько-волинського князівства, яке охоплювало західну частину Поділля. Між ним та зайнятою кочівниками територією існував «буфер» - Болохівська земля - 
напівзалежна від Орди форма давньоруської державності, точні кордони якої ще не встановлені. До створення у 1565 р. Брацлавського воєводства, його територія входила до складу Волинської землі, а деякі джерела їі відносять до Київської землі (Крикун, 2008). До воєводсько-повітового адміністративно-територіального устрою (впровадженого у ВКЛ за зразок польського за кілька років до Люблінської унії) на Східному Поділлі існував волосний устрій. До волосних центрів відносилися поселення з замками - Сокілець, Брацлав, Звенигород (Гедзь, 2010). Хроніст Длугош (Dlugossi, 1712, р.314) зазначає такі укріплення (замки), які відвідували з інспекцією у 1411 р. король Ягайло та Великий Князь Вітовт: Київ, Черкаси, Звенигород, Сокалець, Каравул, Брацлав, Кам'янець, Львів, Глиняни. Каравул, Сокалець та Звенигород припинили своє існування у XVI ст. (про знищення Звенигорода $\epsilon$ окрема згадка (АЮЗР, 1876, с. 23). Найбільш щільно укріпленнями та митницями був забудований басейн Південого Бугу - його контролювали Вітовка, Соколець, Ябу-городок, Вітовтів Міст, Брацлав та Вінниця (Рис. 2.) - 3 цього виходить, що це була основна транспортна артерія Східного Поділля, яка крім цього, забезпечувала контроль держави над усім Східним Поділлям. На Середньому Подністров'ї в межах Східного поділля тоді був лише один опорний пункт - Караул (біля Рашкова) - тиражовані в історіографії данні про існування в той час нібито укріпленого Ямполя автори спростували ще кілька років тому (Литвинчук, 2019), а розташовані північніше Могилів, Калюс та Бакота належали вже Подільскому воєводству Польщі. Тільки гирло Дністра контролювалось Чорногродом, Маяком, а узбережжя Чорного моря - Качибеєм та Дашевим. Рівнинну степову зону міжріччя Дністра та Південного Бугу було важко насичити достатньою кількістю оборонними опорними пунктами $з$ огляду на те, що їх можна було зручно обходити та рухатись далі під час збройного наступу, через що оборона краю та митний контроль тримався на контролі річок та їхніх гирл. На Дніпрі Вітовтом теж були збудовані оборонні укріплення - місто св. Іоана (Scriptores rerum Prussicarum, 1866, s.222) та Вітовтова митниця (Белецкая, 2018). До нашого дня дійшло іконографічне зображення т. зв. «Вітовтої бані» біля впадіння річки. Чичиклія до Південого Бугу на карті Старої та Нової польщі С. Сарницького 1587 р. (Рис.1.) На зображенні бачимо круглу або квадратну споруду, перекритою банею 3 брамою на першому ярусі та галерею бійниць на другому, що дозволяє нам припустити, що мова йдеться про оборонну споруду. Крім графічного зображення існують ще описи XVII ст., які свідчать про Вітовтову баню як перекриту куполом споруду (Белецкая, там само), але у будь якому випадку ми маємо справу 3 поодинокими фортами-митницями, які не утворювали оборонні комплекси. Відповідно, митний та військовий контроль Вівтовта виглядає як передумова появи довготривалих фортифікацій міського типу у регіоні.
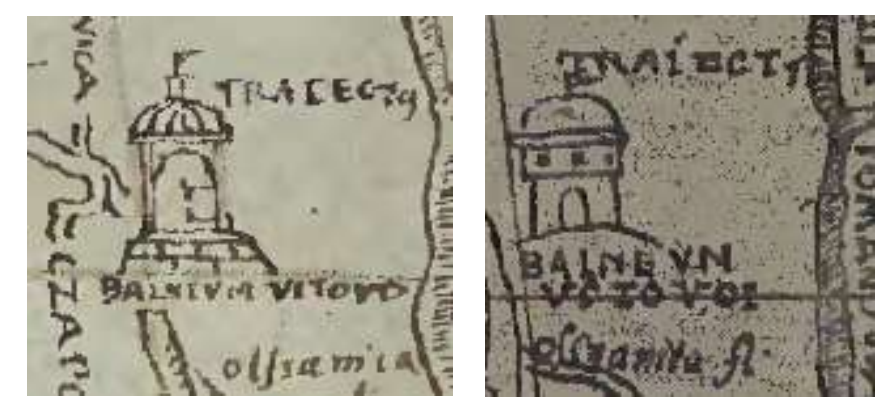

Рис. 1. «Баня Вітовта» на різних варіантах карти Сарниџького 1585 p.

У 1432 відбулася знакова подія, які обумовила життя Поділля на найближчі 137 років (до Люблінської унії) - воно було розділено між Польщею та Литвою і саме за останньою 
залишилась східна частина. Це зумовило відмінність у політичному и економу житті Західного та Східного Поділля. Так, на Східному залишався існуючий волосний поділ, а його територія не мала самостійності у адміністративному устрою князівства, залишаючись частиною Волинської землі. Рубіж XV-XVI ст. відзначилося занепадом державних прикордонних укріплень та руйнівними набігами татар. Так, ще у 1494 р. королівський люстратор, відряджений до ревізії західнополдільських замків, не доїхав до Летичова (який був найближчим прикордонним державним замком 3 Литвою) через propter tiraorem Tartarorum (страх перед татарами) (Мальченко, 2001, с.32; ZD. 1877, s.115-116). Перестали існувати як укріплення Тарговиця, Караул, Звенигород, Сокілець, Новий городок. Під контролем татар опинилися Качибей, Дашів (Очаків), Маяк та Чорногрод.

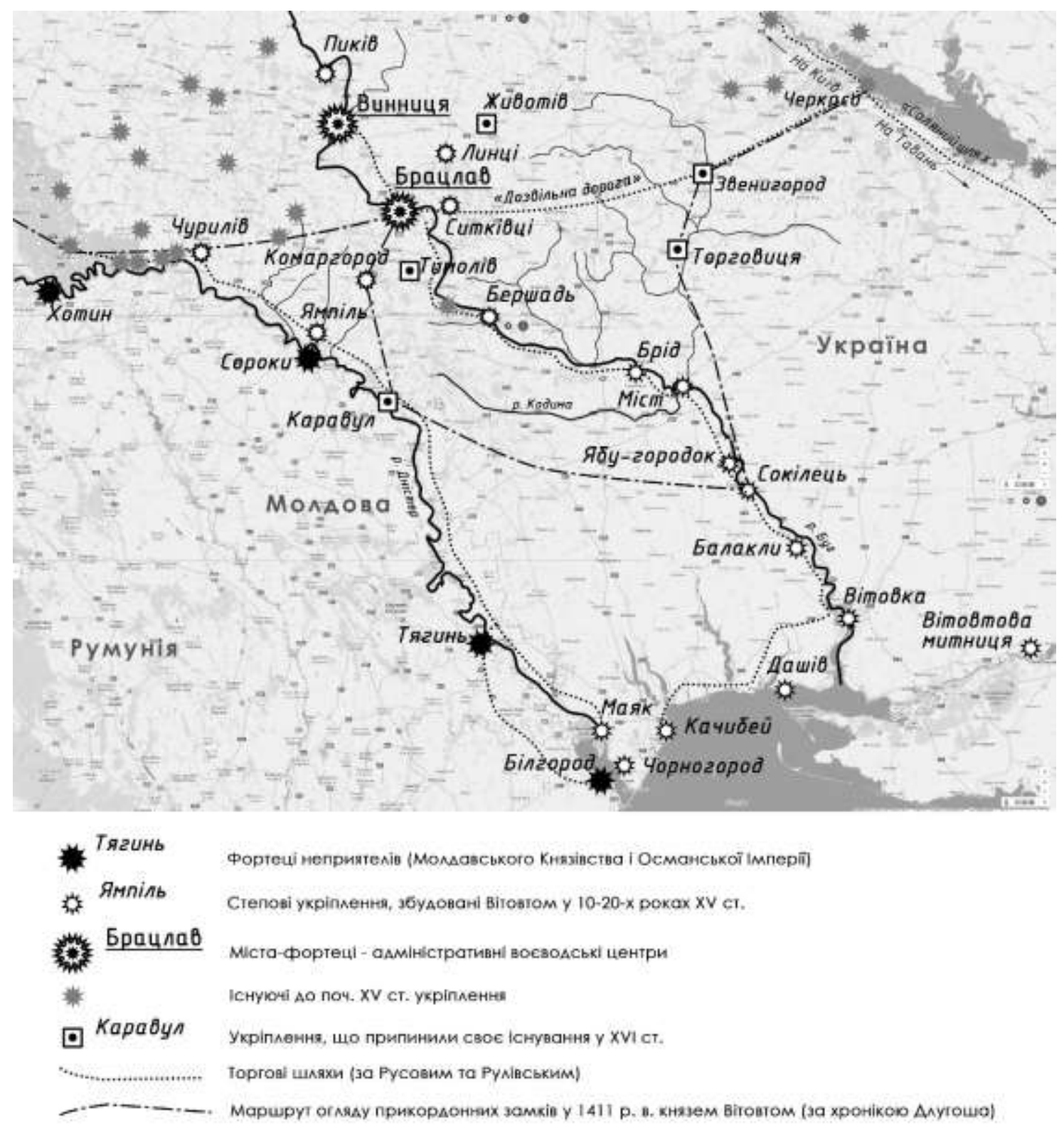

Рис. 2. Схема військової колонізації українського прикордоння у XV cm.

Прогалина оборони на відтінку Звенигород-Тарговиця відкрила татарам прямий шлях на українські землі аж до Львова (т. зв. Чорний шлях, який, ймовірно, існував і раніше, але почав використовуватись татарами 3 кін. XV ст. для набігів та виводу ясира до Криму). Ця прогалина так і не була закрита впродовж всього існування Речі Посполитої. Продовжували функціонувати та підтримуватись замки у Брацлаві (де був митний прикомірок) та Вінниці. 
У Вінниця замок був відбудований у 1512 р., відремонтований у 1552, перенесений на нове місце з містом у 1558 р. За люстрацією 1545 р. обидва замки перебували у незадовільному стані.

Після прилучення Брацлавського воєводства до Польщі розпочався новий етап військової урбанізації. Родючі українські земля Брацлавщини прибирають до рук польські магнати, які впроваджують осадництво нових та розбудову старих укріплених міст. У I половині XVII магнатським родинам належали наступні укріплені міста:

- Замойським - Рашків, Кам’янка, Ямпіль, Буша, Стіна, Чернівці, Томашпіль, Комаргород, Красне (9 міст)

- Збаразьким: (Збараж Новий, Губин, Смагронь (?), Прилука, Спичинці, Погребищі, Животів, Монастиріщі, Зюбриха, Немирів, Ладижин, Бершадь. Баланівка, Ободівка, Босівка (15 міст)

- Вишневецьким: Умань, Івангород, Соколівка, Зелене, Воронівка, Браїлів, Кипіїівка, Тульчин, клебань, Гайсин, Тростянець (11 міст)

- Потоцьким: Яруга, Грушка, Новоград (3 міста)

- Сенявським: Кублич, Городок (2 міста)

- Корецьким: Кальник, Іллінці (2 міста)

- Острозьким: Липовець (1 місто) (тут слід зазначити, що внаслідок збро’ного наїзду Острозькі захопили Рашківський ключ Замоських та тримали його довгий час в себе)

- Заславським (Бузівка)

- Пісочинським: Пісочин (1 місто)

- Язловецьким: Мурафа (1 місто)

Ці заможні магнатські роди заволоділи цими величезними латифундіями через купівлю земель у дрібної місцевої, переважно руської шляхти. Тем не менш, ще у XVII ст. окремі маєтки Брацлавщини були в руках представників старих земянських родів: так, Четвертинські тримали Христопіль, Слупці - Куну, Ярошщинські - Бабин, Кохановські Коханів. Невідома належність Кішляка та кількох неідентифікованих (за картою Боплана) міст: Самойлівки, Вахногреблі, Себастьяновки, Линьовки, Тимпонівки.

Таким чином, перед нами стоять наступні питання. Чи була мережа новозакладених укріплених міст кін. XVI-поч. XVII ст. дійсно «новою» чи базувалась на урбаністичній спадщини русько-литовської доби? Яка була стратегія оборони регіону? На кого була розрахована і наскільки ефективно захищала?

О. Мальченко на перше питання дає однозначну відповідь - магнатська приватновласницька урбанізація використовувала каркас державних оборонних укріплень русько-литовської доби. До такого висновку він приходить, узагальнюючи процеси військової урбанізації на всіх прикордонних воєводствах, зокрема, Київському та Подільському. Але, як ми бачимо на підставі вже викладеного матеріалу, Брацлавське воєводство було цілковито приватновласницьким. Жодне 3 давніх великокнязівських укріплень не поновлювалось після руйнувань (Сокілець, Звенигород, Караул (який був наданий ще Вітовтом у приватне володіння), система укріплень та митниць на Південному Бузі). Натомість, факти нової локації міст на давніших укріпленнях чи городищах нам теж відомі. Передусім, це заснування Томашполя на городищі Драгушов, Буші на місці Здіслава, поновлення Красного, Чернівців на місці Скіндерполя та інші. Канцелярська мова давніх привілеїв та надань не надає чіткої відповіді про стан оборонних комплексів давніших поселень та їхню придатність до повторного використання. Таку інформацію можуть надати лише натурні обстеження сучасної містобудівної ситуації та історична картографія. Так, 
наприклад, у смт Томашпіль (яке офіційно вважається закладеним у 1616 р. Томашем Замойським), у центральній частині спостерігається овал вулиць, які окреслюють стару частину міста - ймовірне городище Драгушов. Стара частина Брацлава позначена на картах кін. XVIII ст. (Ричков, 2016) і прочитується у сучасній топографії. Відсутність комплексних історико-містобудівних досліджень міст Брацлавщини не дозволяє вивести статистичних даних про повторне використання існуючих урбаністичних оборонних комплексів новими власниками.

Питання державної політики в плані оборони від зовнішнього загарбника на Брацлавщини теж насправді не стоїть - в умовах суцільного приватного землеволодіння в регіоні впровадити якусь єдину систему оборони було неможливо, адже ж під системою мається на увазі цільність та єдність елементів, що ії складають, а як цього можна було досягти, коли відносини між сусідами-латифундистами часто були непростими? Незважаючи на прикордонний статус воєводства (межування з Молдавією, Кримським ханством), на більшості його території був відсутній митний контроль - митні прикомірки були тільки у державних містах - Вінниці та Брацлаві (які відносились до Волинської землі) (Колесников, 2019, с. 58) і лише у XVIII ст. митні комори з'являються у брацлавському Придністров’ї- у Цекіновці та Рашкові (Dz. Handlowy, 1787, s.495-496). Ці митниці не були пов'язані з урбаністичними оборонними комплексами, адже ж у Цекінівці ніколи не було оборонних укріплень і у XVII ст. вона ще була селом. В той самий час, у сусідній Кісниці станом на 1770-ті існувало зруйноване регулярне бастіонове укріплення, яке, як зазначав Г. Мюнц, було б добре використати для впровадження та охорони тут митниці ${ }^{1}$ (Jana Henryka Müntza podróże malownicze po Polsce i Ukrainie (1781-1783).

Для відповіді на третє питання - для захисту від кого будувались урбаністичні оборонні комплекси, треба добре проаналізувати міста, які складали частину латифундій одного власника (Замойських, Збаразьких чи інших). На сьогодні таких досліджень в Україні не проведено, отже можемо виходити хіба що 3 картографічних джерела XVII-XVIII ст. Традиційно вважається, що вони існували для захисту держави від агресії сусідніх країн, але ще у XIX ст. ця точка зору підлягала критиці. Грушевський $(1890$, с. 35) та ВладимирськийБуданов (АЮЗР, 1905, с. XXXVII) вважали, що приватновласницькі укріплення були малоефективними для оборони проти татар. Дійсно, татарські напади пустошили та руйнували укріплені міста (переважно - середмістя, а замки залишали нездобутими). Але зростаюча кількість укріплених поселень звужували їхні можливості вільного пересування Україною, а для місцевого показаченого населення, навпаки, давала можливість здоганяти татар під час їхнього повертання до Криму та повертати здобич. Яскравим прикладом тут виступає фортифікаційно-урбаністична діяльність Каліновського, який отримав за постановою сейму 1606 р. «Гуманську пустиню» (пустинею іï зробили набіги татар, обидва шляхи яких оточували регіон). Осадивши і укріпивши місто Умань, він найняв військо надвірних козаків для охорони краю, які розбили тут татар у 1629 під час чергового набігу. Історичних відомостей про руйнування Умані татарами, чи облоги ії̈ військами інших держав відсутні. Територія колишньої «пустині» починає залюднюватись (Рис.3).

\footnotetext{
${ }^{1}$ Кісниця (нині - с. Велика Кісниця Ямпільського р-ну) у 1594-1596 рр. називалась «селищем», у 1606 селом, у іншому документі того ж 1606 р. - містом (ZD, 1894, s.393-581) . У 1656 р. шведський посол Гільдербрант занотував у свому щоденнику відомості про «добре зроблений шанець» у Косниці, аналогів якого він не бачив «по всій Україні» (Олянчин, 1937).
} 


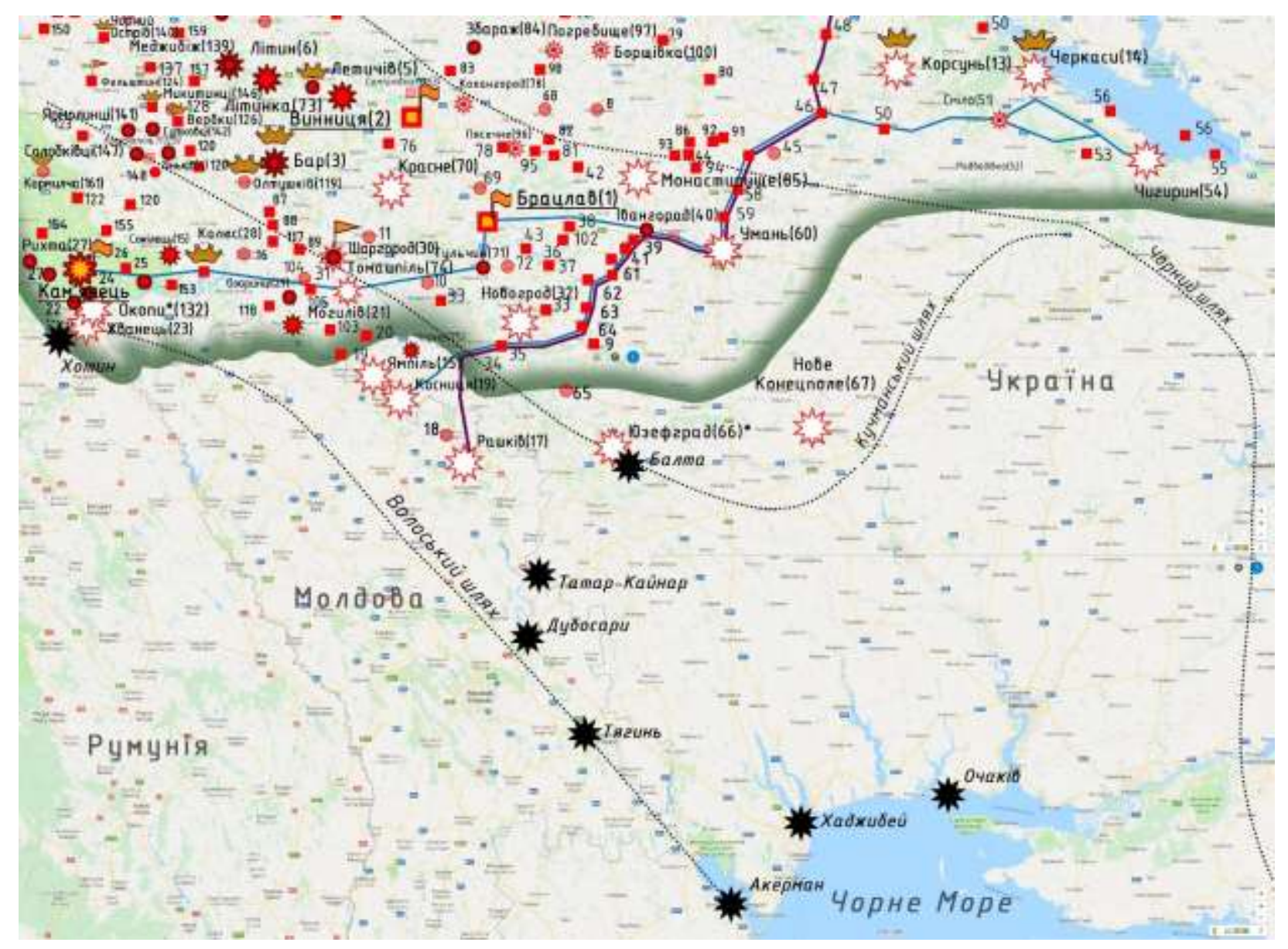

Рис.3. Розбудова приватновласницьких укріплених міст у кін. XVI-XVIII cm.

3 цього виходить, що Річ Посполита як держава у кін. XVI-поч. XVII ст. розглядала землі Брацлавщини, які частково лежали у «пустинях» як винагороду, яку можна надати за службу найбільш дійовим та відданим державним діячам. Внаслідок малої залюдненості та занепаду старих торгівельних трактів ця територія не була економічно важливою для держави на той момент - це ми довели, коли проаналізували наявність митних комор в регіоні. Магнати скеровували власний капітал та зусилля на укріплення старих та нових міст та отримували прибуток, частину якого забирала держава як податок. Скористатися результатом цієї роботи держава змогла лише через століття - поява державних митних комор у XVIII ст. це підтверджує. В цей час також завершилася демаркація південного кордону держави.

Зацікавлені у економічному розвитку (а точніше, прибутків) магнати змушені були утримувати укріплення та залоги в них не тільки від іноземного неприятеля, але й від нападів сусідів під час характерних для феодалізму панських чвар. Можемо припустити також, що укріплення слугували й захистом майна та місцевої канцелярії феодала від ймовірних повстань (перші з яких пролунали ще у кін. XVI ст., але у цьому разі може йти мова лише про замкові укріплення, оскільки середмістя зі своїми укріпленнями належали міщанам, а часто ними ж і охоронялися). Сама система укріплених поселень працювала в межах кожної латифундії автономно і була розрахована для забезпечення керування вотчиною феодалом та збирання поборів з населення. 


\section{Типологія урбаністичних оборонних комплексів}

Під час натурних досліджень урбаністичних оборонних комплексів Брацлавського воєводства нами були виділені характерні закономірності співвідношення та розташування елементів цих комплексів, які відрізняються сталою повтореністю (табл. 1).

Передусім, розберемо розташування замків у системі урбаністичних оборонних комплексів. Традиційно давньоруські міста мали тридільну систему оборони «городпідгороддя-посад», в якій город (дититець) як правило, мав мисове розташування і був неприступний з однієї сторони завдяки природнім умовам і захищався штучно зміненим ландшафтом (вали, рови, канали) з іншої. Така схема на прикордонних землях працювала і у XVII-XVIII ст. - за нею були уфортифіковані Брацлав, Немирів, Ладижин. Замок захищався укріпленнями середмістя і виконував роль цитаделі.

У іншій спосіб укріплювались Чернівці, Томашпіль, Вінниця на лівому березі - там замок та середмістя розташовувались на певній відстані і з'єднувались дорогою. Нарешті, третій тип, протилежний першому - коли замок був «вбудований» у оборонний периметр середмістя, додатково захищаючи підступи до міста. Такий спосіб був характерний для міст ранньомодерного часу (Новоград, Коханів, Пісочин, Рашків), де використовувалась вже новітня на то час урбаністична система.

Крім цього, на тип оборонного комплексу впливало і його функціональне призначення. Основні функції ми навели вище - це контроль над переправами та шляхами 3 метою отримання грошових прибутків та адміністрування. Деякі міста охороняли стратегічно важливі переправи (Немирів, Чернівці), деякі - виключно суходольні шляхи (Новгород, Коханів). Воєводські міста Брацлав і Вінниця поєднували в собі кілька функцій, крім цього, в них були розташовані митні прикомірки.

Хронологічно можна періодизувати військову колонізацію Брацлавщини. Перша хвиля припадає на II пол. XIV ст. - момент визволення регіону з під влади Ординців. Тоді, за літописом, князь Ольгерд укріпив подільські міста. Друга відноситься до правління Вітовта I (поч. XV ст.) та розквіту державі в ці часи. Третя відбувається за часи старостування Острозьких та залучення колоністів з Волині (кін. XV-поч. XVI ст). Майже весь XVI ст. відзначився тривалим занепадом ВКЛ, закономірним підсумком якого було його злиття 3 Польщею - вже після Люблінської унії 1569 р. розпочинається четверта хвиля урбанізації Поділля, яка тривала (хоч і з невеликими перервами) до 1648 р. В цей час нові укріплені міста осаджувались на «пустках», грунтах існуючих сіл, модернізувались існуючі міста. Внаслідок цього виділяються наступні типи оборонних комплексів:

- міста на давніх поселеннях та городищах. Відбивається у актовій джерельній базі у вигляді згадок про давні топоніми перезаснованих міст (Драгушів-Томашпіль, Здіслав-Буша, Чернівці-Скіндерполь-Чернівці (повернення первісної назви). На місцевості у плануванні вулиціь та парцеляції кварталів простежуються овали оборонних периметрів давньоруських або русько-литовських передмість (Вінниця, Томашпіль);

- нова локація поруч зі старою. Відзначається збереженістю первісної планувальної структури, яка опиняється на передмісті новозаснованого міста, яке найчастіше має регулярну структуру;

- модернізація старого міста. Представляє собою оборонний комплекс, насичений різночасовими елементами. 
Табл. 1. Типологія урбаністичних оборонних комплексів Брацлавщини

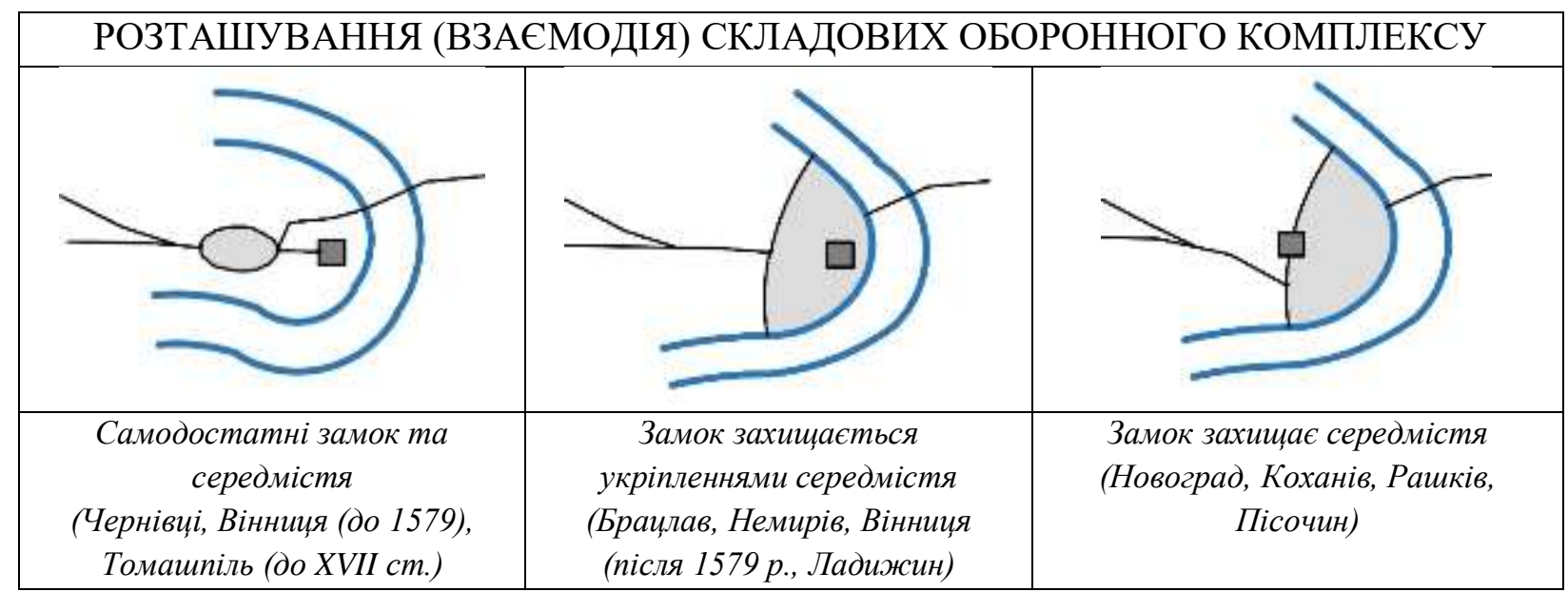

(Кісиия, Рашків, Чернівиі)


Розташування на місцевості теж корелюється 3 хронологічним періодом заснування укріпленого міста. Так, міста, що були засновані на руському праві (що в межах Брацлавщини хронологічно відповідає періоду до Люблінської унії) розташовувались на пануючий височині (миси, кряжи, пагорби, Табл. 2), тоді як для локації пізніших міст (на польському чи магдебурзькому) праві обиралися низинні та рівнинні території (Табл.3). Можемо пов'язати це з розповсюдженням артилерії, які не була пристосована до стрільби додолу (або ж була малоефективна для цього).

Табл. 2. Урбаністичні оборонні комплекси, розташовані на узвищах (XIV-XVI ст.):

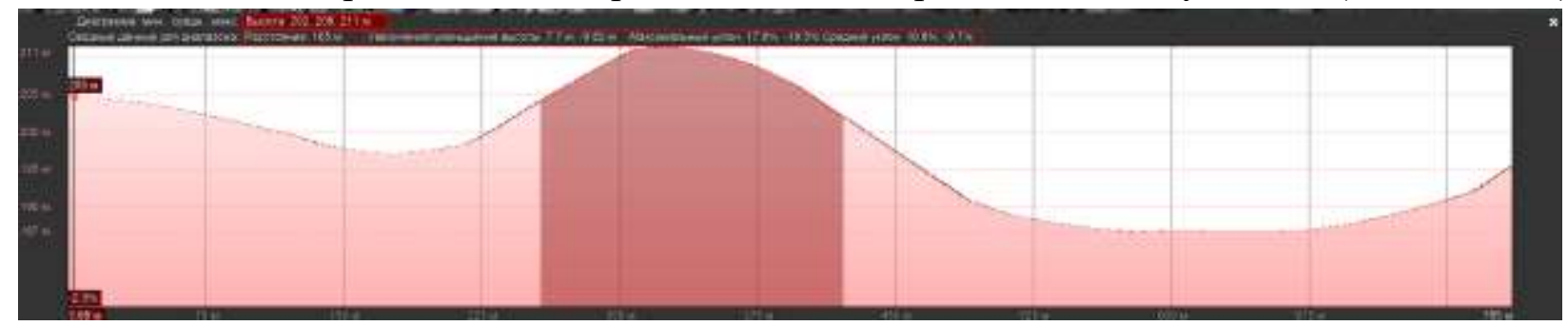

Браилав, ХVI cm.

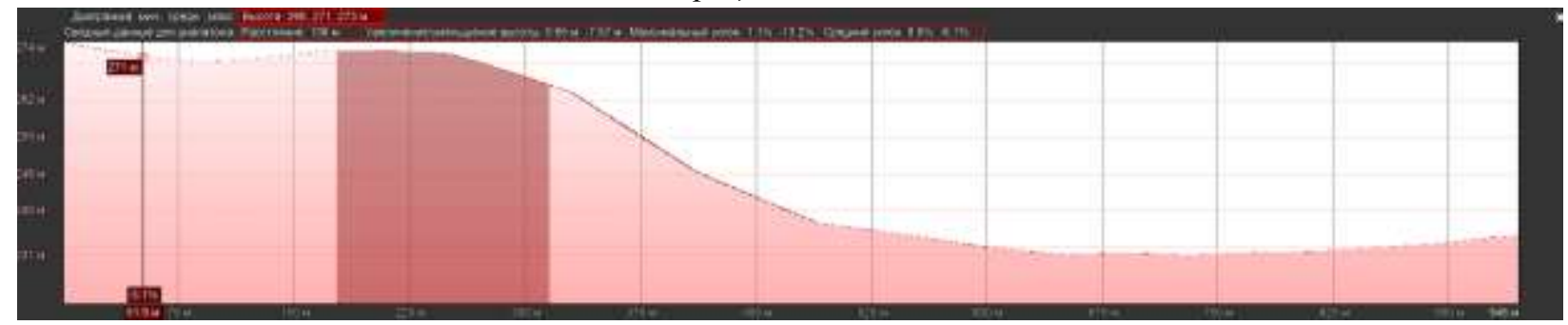

Вінниия (Старе місто), до 1558 p.

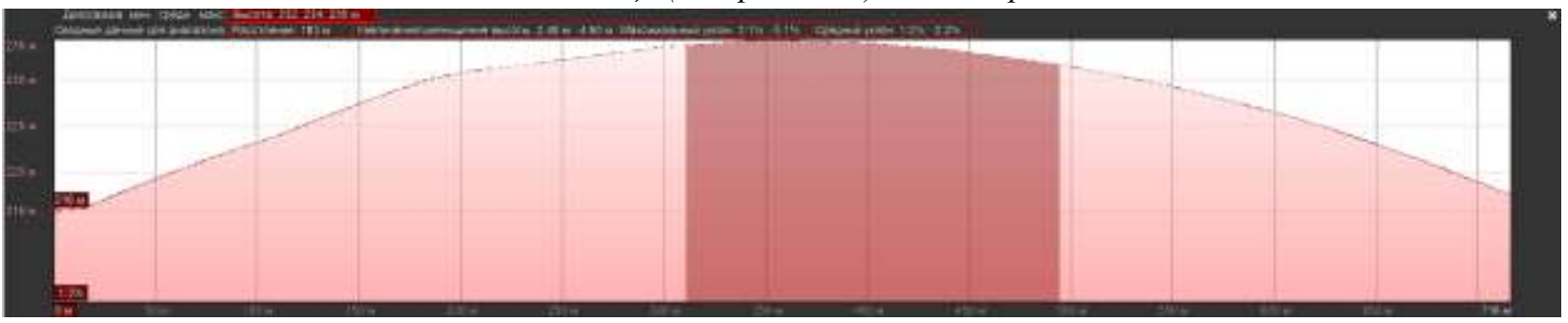

Томашпіль (городище Драгушов), XVI cm

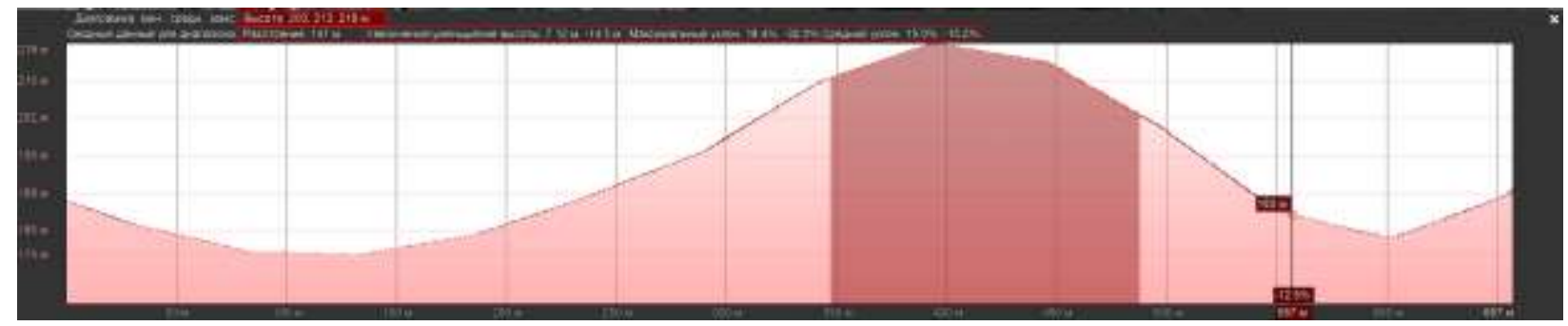

Стіна, XVI cm

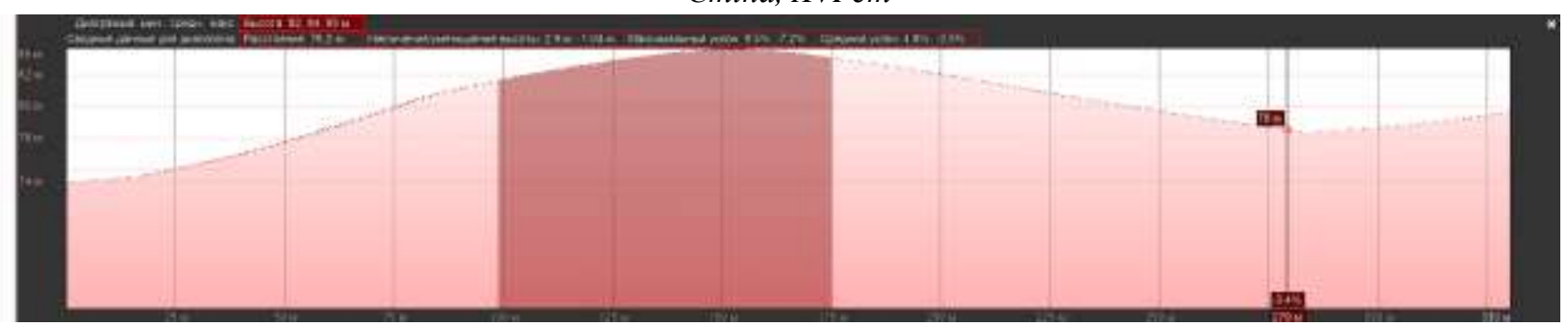

Буша, XVI cm. 


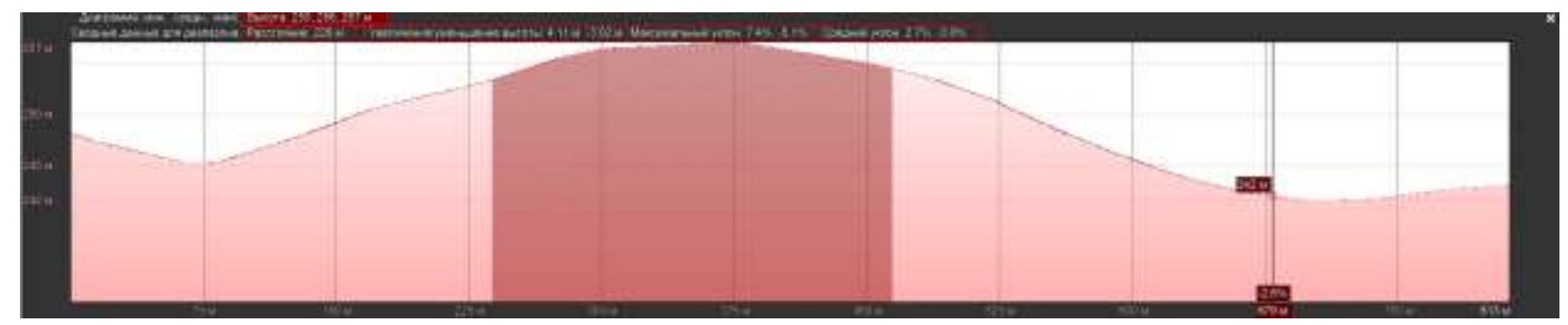

Красне (стара частина), до XVII cm.

Табл. 3. Урбаністичні оборонні комплекси, розташовані в долині (кін. XVI-XVII ст.):
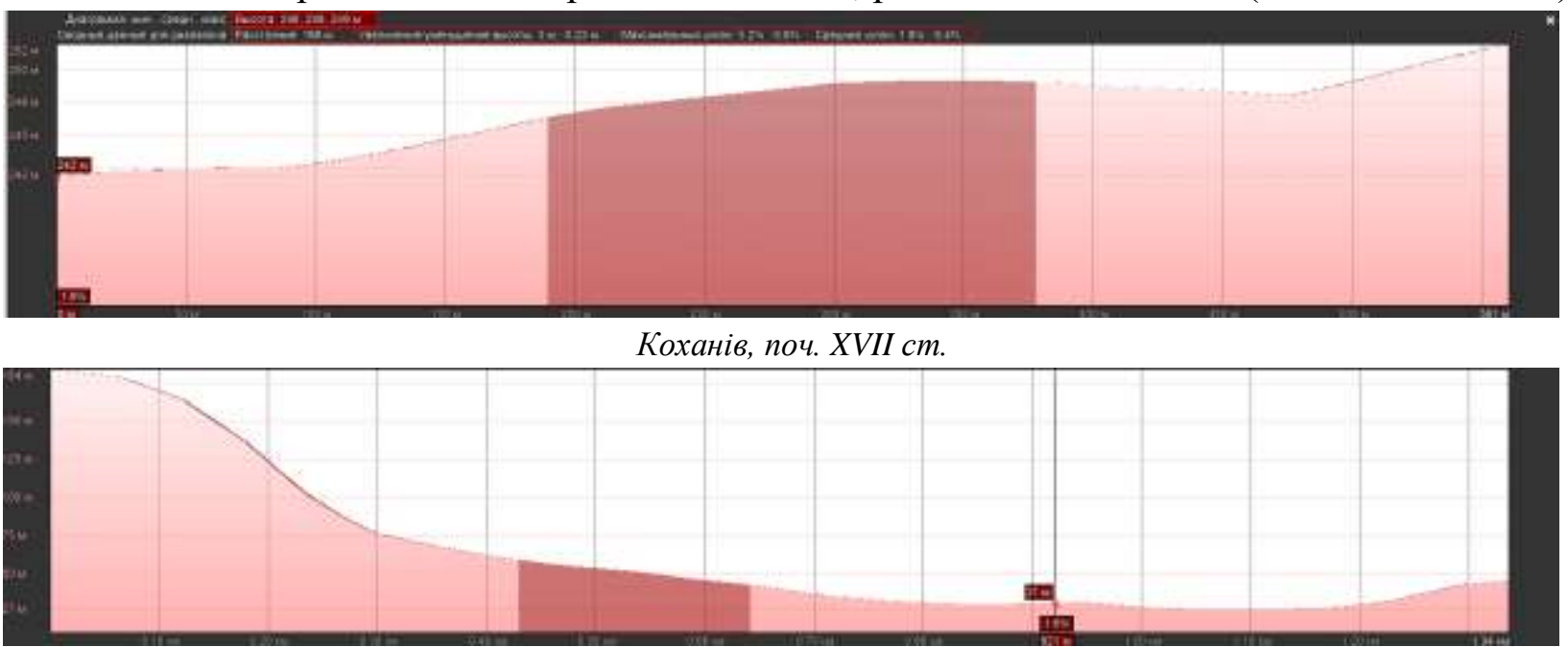

Рашків, 1600 p.

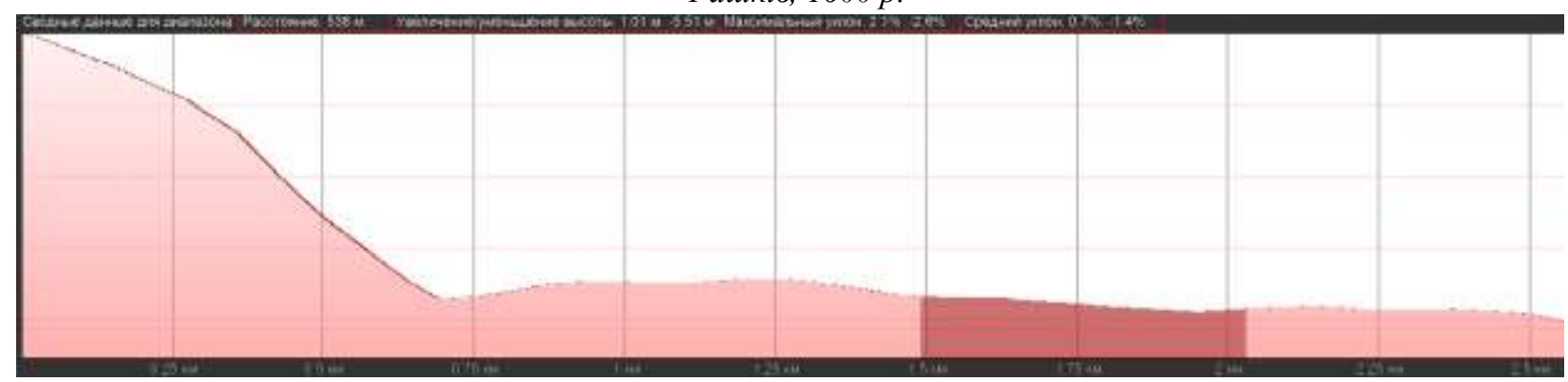

Ямпіль, I пол. XVII cm.

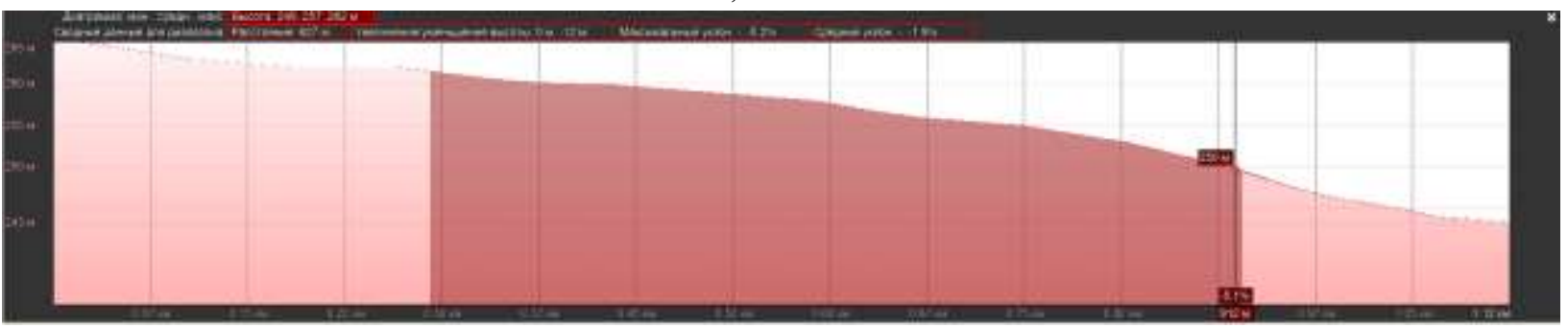

Красне (нове місто), I пол. ХVII $\mathrm{cm}$.

Артилерія з'являється в Україні з XV ст., але масово озброюють нею укріплення з XVI ст., що зазначають люстрації 1545 та 1552 років. У випадку Вінницького замку варто зауважити один цікавий момент - люстратор у 1552 році зазначає, що замок розташовано незручно через те, що навпроти замкової гори є інша гора, з якої замок може обстрілювати (артилерією) неприятель. Враховуючи, що цей замок стояв 40 років станом на 1552 р., виходить, що його збудували десь у 1512 р. (достовірність переказу залишається відкритим питанням), тобто вже у артилерійську епоху, але не пересунули його на інше місце. Відповідь на цей парадокс може бути банальною: замок не будували на порожньому місці, а відновлювали старий, що логічно, враховуючи недовговічність дерев'яних конструкцій. 
Вади у розташування замків в цих же роках зустрічаються i на прикладі інших південноукраїнських замках (Мальченко, 2001). Відповідно, маємо справу з інерцією усталеної традиції осадництва міст від давньоруських часів, яка не поспішала уступати місце нововведенням ранньомодерної доби. На ілюстраціях нижче приведені приклади різніх підходів у використанні рельєфу міст на Брацлавщини (темним кольором виділені межі розташування оборонного комплексу.

Важливим доповненням тут буде, те, що урбаністичні оборонні комплекси першого типу характеризуються нерегулярним способом просторового розпланування. Обриси укріплень замку та середмістя являють собою овали. Межі парцель та кварталів всередині міст розташовані під непрямими кутами, їхні габарити різні. На противагу ним, укріплені міста другого типу розплановані за регулярними планами, із застосуванням новітніх на той момент інженерних рішень, зокрема, бастіонів. Бастіонові замки були у Коханові, Верхівці, Кісниці та Пісочині, бастіонові укріплення середмістя - у Рашкові, Новому Конєцполі Ямполі. Регулярні замки з дерев'яними вежами були у Вінниці (новий замок) та у Рашкові.

\section{Висновки}

За результатами дослідження ми приходимо до попереднього, але досить важливого для подальших досліджень висновку: урбаністичні оборонні комплекси міст Брацлавщини, які складались із замку, укріпленого середмістя, та у окремих випадках - укріпленого передмістя, були призначені не як складова стратегічної державної оборони прикордоння, а як адміністративно-фіскальні пункти, які охороняли приватні маєтності вищих верств польської шляхти, які вже у свою чергу, фінансували зі своїх прибутків «польну» оборону прикордонних територій.

Питання стратегії оборони, яка у XVI-XVII ст. повністю перейшла у приватні руки вимагають подальших досліджень на прикладі найбільших у регіоні маєтностей: Калиновських, Забаразьких, Замойських. Необхідно провести комплексі історикомістобудівні студії кожного населеного пункту для з'ясування моделі побудови урбаністичних оборонних комплексів, принципи розташування складових їхніх систем i типів оборонних споруд, ідентифікації збережених реліктів. Отриманні знання зможуть надати розширену відповідь на питання, як саме були розставлені пріоритети у оборони міста, іншими словами - проти кого боронились у першу чергу: іноземних загарбників чи степових кочівників, сусідніх феодалів 3 їхніми приватними військами чи місцевих повстанців.

Встановлений взаємозв'язок між часом уфортифікування населеного пункту та його просторово-планувальними характеристиками теж потребує поглиблених досліджень на предмет повторюваності в межах всього регіону та можливих комбінацій, що дозволить виявити композиційні особливості урбаністичних оборонних комплексів Брацлавщини у порівнянні з іншими регіонами держави.

\section{Використана література та джерела:}

Budzińska, E., 1982. Jana Henryka Müntza podróże malownicze po Polsce i Ukrainie (17811783).

Czołowski, A., 1892. Dawne zamki i twerdze na Rusi Halickiej. Teka konserwatorska. Lwów. Dlugossi, I., 1712. Historiae poloniae, 2, Cracouiensis.

Fürstenhoff, J. G. M. von, 1755. Sammlung von Festungsplänen. II. Planes von Italien, Ungarn, Pohlen und denen Nordischen Königreichen. 
Liske, F. K, 1876. Cudzoziemcy w Polsce : L. Naker, U. Werdum, J. Bernoulli, J.E. Biester, J. J. Kausch. Lwów: Gubrynowicz i Schmidt.

Rolle, A. J., 1880. Zameczki podolskie na kresach multańskich. W: 3 t. Warszawa: Gebethner i Wolff ; Kraków: G. Gebethner i Spółka, 1880 (Kraków : Wł. L. Anczyc i Sp.).

Scriptores rerum Prussicarum, 1866. Die Gesichtsquellen der preussischen Vorzeit bis zum Untergange der Ordensherrschaft, 3. Leipzig.

Tarnawski, A., 1935. Działalność gospodarcza Jana Zamoyskiego, kanclerza i hetmana $w$. kor. (1572-1605). Lwów, Warszawa: skł. gł. Kasa im. Rektora J. Mianowskiego, Instytut Popierania Polskiej Twórczości Naukowej

Volumina Legum, 1889, 9. Kraków: Nakł. Akademii Umiejętności.

Źródła dziejowe, 1877. T.5. Lustracye królewszczyzn ziem ruskich Wołynia, Podola i Ukrainy z pierwszej połowy XVII wieku. Warszawa: Główny skład u Gebethnera i Wolffa.

Źródła dziejowe, 1894. T.12. Polska XVI wieku pod względem geograficzno-statystycznym, Ziemie ruskie. Ukraina (Kijów-Bracław). Warszawa: Główny skład u Gebethnera i Wolffa.

Алеппский, П., 1896-1900. Путешествие антиохийского патриарха Макария в Россию в половине XVII века, описанное его сыном архидиаконом Павлом Алеппским : (По рукописи Моск. гл. арх. М-ва иностр. дел). Перевод с арабского Г. Муркос. Москва : Общество во истории и древностей российских при Московском университете.

Архив Юго-Западной России, издаваемый временною комиссиею для разбора древних актов высочайше учрежденною при Киевском военном, Подольском и Вольлнском генералгубернаторе, 1886. Киев: типография Г. Т. Корчак-Новицкого, 1886.

Байцар, А., 2017. Украӥнські етнічні землі в атласі Джованні Антоніо Рищци Занноні 1772 p. [online] Доступно: <http://baitsar.blogspot.com/2017/06/1772.html> [Дата звернення 1 жовтня2020]

Бевз, М., 2002. Студії архітектурно-містобудівельного розвитку міста Белза 11-20 ст. Вісник інституту «Укрзахідпроектреставрація», 12.Львів.

Бевз, М., В., 2019, Архітектурно-розпланувальні принципи ренесансного “ідеального міста“, реалізовані при закладенні та розбудові Жовкви наприкінці XVI та у XVII столітті. Вісник Національного університету “Львівська політехніка”. Серія: Архітектура, 1. Львів: Видавництво Львівської політехніки, с.68-96.

Белецкая, О., 2018. Имя великого князя литовского Витовта в названиях Северного Причерноморья XVI-XVIII веков. Lietuvos istorijos studijos, 42. Vilniaus, c.7-28.

Білінський, М., 1926. Вінницький Замок: Історичний нарис з доби 16-18 століть. Вінниця.

Бойко О. та Слободян В., 2006. Розвиток та формування урбаністичної структури Белза на основі іконографічних та архівних досліджень. Белз і Белзька земля. Науковий збірник, 2. Белз, с. 140-166.

Бондар, О., 2014. Чернігівська фортеця в другій половині XVII ст. Сумський історикоархівний журнал, 22.

Боплан, Г.Л., 1990. Опис України. Переклад з французької Я.І.Кравець, З.П.Борисюк. Київ.

Винокур, I. С. та Забашта, Р. В., 1991. Буша: історико-краєзнавчий нарис. Хмельницький.

Гваньїні, О, 2007. Хроніка європейської Сарматії. Переклад з польської Ю. Мицик. Київ: Києво-Могилянська академія. 
Гедзь, Т., 2011а. До питання про існування та локалізацію “степового” Звенигорода [online]

Доступно: <https://www.myslenedrevo.com.ua/uk/Sci/AuxHistSci/HistGeography/Zvenygorod.html> [Дата звернення 1 жовтня2020].

Гедзь, Т., 2011b. До питання про існування та локалізащчію “степового” Звенигорода [online]

Доступно:

<https://www.myslenedrevo.com.ua/uk/Sci/AuxHistSci/HistGeography/Zvenygorod.html> [Дата звернення 1 жовтня2020].

Гедзь, Т., 2012. Соколещька волость та навколишні землі у 1391 ройі [online] Доступно: <https://www.myslenedrevo.com.ua/uk/Sci/AuxHistSci/HistGeography/SokileckaVolost.html> [Дата звернення 1 жовтня2020].

Гедзь, Т., 2013. Шляхи з Києва до Браилава у XV-XVII cm. [online] Доступно: <https://www.myslenedrevo.com.ua/uk/Sci/AuxHistSci/HistGeography/KyivBraclav.html> [Дата звернення 1 жовтня2020].

Гедзь, Т., 2015. Бращлавська волость у 1392 роц̧і [online] Доступно: <https://www.myslenedrevo.com.ua/uk/Sci/AuxHistSci/HistGeography/Braclav1392.html> [Дата звернення 1 жовтня2020].

Дашкеич, Я., 1991. Україна на межі між Сходом і Заходом (XIV-XVIII ст.). Записки Наукового товариства ім.Шевченка, 222, Праці історико - філософської секції, Львів: Видавництво Наукового товариства імені Т.Шевченка у Львові.

Диба, Ю. та Рязанова, Н., 2019. Ягорлик - укріплене містечко на межі трьох держав. Current Issues in Research, Conservation and Restoration of Historic Fortifications, 11. Chełm,Lviv: Rastr-7.

Добролюбький, А. та Смирнов, I., 2011. Кочовики південно-західної Украӥни в XXVII століттях. Київ, Миколаїв: Іліон.

Жовкви (Оконченко, Бев3, 2014), Чернігова (Бондар, 2017), Калуша (Федунків; Лукомська, Малишко, 2015), Івано-Франківська (Лукомська, 2017), Львова (Качор, Могитич), Белза (Бевз; Бойко і Слободян), Луцька (Терський).

Качор, І. та Качор, Л., 2009. Середньовічний Львів. Фортифікації. Львів: Апріорі.

Кисілевський, В., 1966, Опис Правобережної України в Атлясі Йоаннеса Янсонія. Український історик, 3, ч.3-4

Колесников, К.М., 2019. Історія митної діяльності: Украӥна в міжнародних митноторговельних мережах. Навчальний посібник. Дніпро: УМСФ.

Кравцов, С.P., 1993. Принципь регулярного градостроительства Галичины XIV - XVII веков. Кандидат наук. Москва.

Кравченко, В., 2005. Литовська Метрика. - Книга 561: Ревізї̈ украӥнських замків 1545 року. Київ: Наукове товариство ім. Шевченка в Америці, Наукове товариство ім. Шевченка в Україні, НАН України, Інститут української археографії та джерелознавства ім. М. С. Грушевського.

Крикун, М., 2008. Браилавське воєводство у XVI-XVIII столітmях: Cтатmi $i$ матеріали. Львів: Видавництво Українського Католицького Університету.

Кучера, М. П., 1965. Середньовічне городище біля с. Сокільці на Південному Бузі. Археологія, 19, с.201-214.

Логвин, Г. Н., 1959а. Замок в Меджибожі: пам'ятник архітектури $16 \mathrm{~cm}$. Київ: Держбудвидав.

Логвин, Г. Н., 1959b. Замок в Острозі. Київ: Держбудвидав 
Логвин, Г. Н., 1967а, Замок у Хотині. Українське мистецтвознавство, т.1, с.149 - 158.

Логвин, Г. Н., 1967b, Луцкий замок. Культура и искусство древней Руси, Ленинград: Издательство Ленинградского государственного университета, с. 102-107.

Логвин, Г. Н., 1967с. Хотин: замок. Київ: Мистецтво.

Лукомська, 3. В., 2007. Розвиток розпланувально-композиційної структури середмістя Івано- Франківська у XVII-XX cm. Кандидат архітектури. Львів: Національний ун-т "Львівська політехніка".

Лукомська, 3. та Малишко, О., 2015, Містобудівна спадщина Калуша періоду XV XVIII ст. Сучасні проблеми дослідження, реставрації та збереження культурної спадщини: 3б. наук. пр. з мистецтвознав., архітектурознавства і культурологї, 11. Київ: Ін-т проблем сучас. мистец. НАМ України, Фенікс, с.183-188.

Литвинчук, I., 2019. Ямпіль - ренесансне місто-фортеця на Дністрі у світлі маловідомого картографічного джерела 1810 р. У: Збірник матеріалів «Археологія \& Фортифікаиія України», 9, с. 152-157.

Мальченко, О., 2001. Укріплені поселення Брацлавського, Київського і Подільського воєводств (XV- середина XVII ст.). Київ: Інститут української археографії та джерелознавства ім. М. Грушевського НАН України

Мацюк, О. Я., 2005. Замки і фортеці Західної України = Castles and Fortesses of Western Ukraine: історичні мандрівки. Львів: Центр Європи.

Михайловський, В., 2002. Замки на піску. Рещензія на: Олег Мальченко. Укріпленні поселення Браилавського, Київського і Подільського воєводств (XV - середина XVII cm.). Київ: Інститут української археографії та джерелознавства НАНУ.

Могитич, Р., 1993. Львів- місто фортеця. Віче, 15,16. Львів.

Могитич, Р., 2008. Передміські укріплення Львова. Вісник УЗПР, 18. Львів, с.106-116.

Нагнибда, Р., 2018. Літописи церковні Балтського повіту Подільської губернії 18661899. Дрогобич : Коло.

Нагнибіда, Р., 2011, Оборонні укріплення міст і містечок подільського краю XIII XVIII ст. У: Погорілець, О., ред., 2011. Науковий вісник «Межибіж»: Матеріали четвертої науково-краєзнавчої конференції «Стародавній Меджибіж в історико-культурній спадщині Украйни». Меджибіж-Хмельницький: ПП Мельник А.А.

Нельговский Ю. П., 1979, Некоторые особенности замков Подольских земель Украины XVI - начала XVII вв. Архитектурное наследство, 27. Москва: Стройиздат, с.89-96.

Новгородская первая летопись старшего и младшего изводов, 1950. МоскваЛенинград, с.475-477

Оконченко, О., 2012. Значення терміну "замок" при дослідженні оборонної архітектури Речі Посполитої. II Всеукраїнська науково-практична конференція Кам'янець-Подільського державного історичного музею-заповідника.

Олянчин, Д., 1937. Опис подорожі шведського посла на Україну 1656-1657. Записки Наукового Товариства ім. Шевченка, 154, с.51-52.

Отамановський, В. Д., 1993. Вінниия в XIV-XVII столітmяx. Вінниця: Континент-прим.

Памятники истории и культуры Винницкой области, 1990. Материалы к своду памятников истории и культуры народов СССР по Украинской ССР, 8. Киев.

Рибчинський. О.В., 2017. Формування і ревіталізація середмість історичних міст України. Доктор наук. Львів: Національний університет «Львівська політехніка» 
Ричков, П.А., 2016. Нотатки до урбаністичної історії Брацлава. У: Вінницький обласний краєзнавчий музей, 2016. Міста і містечка Поділля від доби Середньовіччя до початку ХХ ст. Матеріали наукової конференції 24-25 вересня 2015 р. Вінниця, с.314-323.

Русов, А. А., 1876. Русские тракты в конце XVII и начале XVIII веков. Киев.

Терський, С.В., 2006. Лучеськ $X-X V \mathrm{~cm}$. Львів: Видавництво Національного університету “Львівська політехніка".

Тичук, Є., 2016. Система оборони Великого князівства Литовського від татарської загрози як причина появи міст східного Поділля. У: Вінницький обласний краєзнавчий музей, 2016. Міста і містечка Поділля від доби Середньовіччя до початку XX cm. Винниця, c. 44-48.

Федунків, 3. Б., 2015. Локалізація замку і міських укріплень м. Калуш XVI-XVIII ст. за історичними та картографічними матеріалами. Праці Центру пам'яткознавства, 27, с.278290.

Філіпова, Г. В., 2016. Укріплення Києва напередодні Північної війни: проект Лямота де Шампійє. Питання історії науки і техніки, 3, с.12-18.

\section{References:}

Aleppskiy, P., 1896-1900. The journey of the Patriarch of Antioch Macarius to Russia in the middle of the 17th century, described by his son, Archdeacon Paul of Aleppo: (According to the manuscript of the Moscow chief architect of the Ministry of Foreign Affairs). Translated from Arabic by G. Murkos. Moskva: Obshchestvo vo ystoryy y drevnostey rossyyskykh pry Moskovskom unyversytete.

Baytsar, A., 2017. Ukrainian ethnic lands in the atlas of Giovanni Antonio Rizzi Zannoni 1772 [online] Avialiable at: <http://baitsar.blogspot.com/2017/06/1772.html> [Accessed1 October2020]

Bevz, M., 2002. Studies of architectural and urban development of the city of Belz $11^{\text {th }}-20^{\text {th }}$ centuries.Visnik institutu «Ukrzakhidproyektrestavratsíya», 12. L'vív.

Bevz, M., V., 2019, Architectural and planning principles of the Renaissance "ideal city", implemented during the founding and development of Zhovkva in the late sixteenth and seventeenth centuries. Visnik Natsínal'nogo uníversitetu "L'vívs'ka politekhníka". Seríya: Arkhítektura, 1. L'vív: Vidavnitstvo L'vívs'koï polítekhníki, pp.68-96.

Beletskaya, O., 2018. The name of the Grand Duke of Lithuania Vytautas in the names of the Northern Black Sea region of the XVI - XVIII centuries. Lietuvos istorijos studijos, 42. Vilniaus, pp.7-28.

Bílíns'kiy, M., 1926. Vinnytsia Castle: A Historical Essay from the 16th-18th Centuries. Vínnitsya.

Boyko O. and Slobodyan V., 2006. Development and formation of the urban structure of Belz on the basis of iconographic and archival research. Belz i Belz'ka zemlya. Naukoviy zbirnik, 2. Belz, pp.140-166.

Bondar, O., 2014. Chernihiv fortress in the second half of the seventeenth century. Sums'kiy istoriko-arkhivniy zhurnal, 22. Sumy.

Boplan, G.L., 1990. Description of Ukraine. Translated from French by Y.I. Kravets, Z.P. Borisyuk. Ki⿱ív.

Vinokur, Í. S. and Zabashta, R. V., 1991. Bush: historical and local lore essay. Khmel'nits'kiy.

Gedz', T., 2011a. On the question of the existence and localization of "steppe" Zvenigorod [online]

Avialiable

at: 
<https://www.myslenedrevo.com.ua/uk/Sci/AuxHistSci/HistGeography/Zvenygorod.html> [Accessed1 October2020].

Gedz', T., 2012. Sokoletska volost and surrounding lands in 1391 [online] Avialiable at: <https://www.myslenedrevo.com.ua/uk/Sci/AuxHistSci/HistGeography/SokileckaVolost.html> [Accessed1 October2020].

Gedz', T., 2013. Ways from Kyiv to Bratslav in the XV-XVII centuries [online] Avialiable at: <https://www.myslenedrevo.com.ua/uk/Sci/AuxHistSci/HistGeography/KyivBraclav.html> [Accessed1 October2020].

Gedz', T., 2015. Bratslav parish in 1392 [online] Avialiable at: <https://www.myslenedrevo.com.ua/uk/Sci/AuxHistSci/HistGeography/Braclav1392.html> [Accessed 1 October2020].

Dashkeich, YA., 1991. Ukraine on the border between East and West (XIV-XVIII centuries). Zapiski Naukovogo tovaristva ím.Shevchenka, 222, Pratsí ístoriko - fílosofs'koï sektsií, L'vív: Vidavnitstvo Naukovogo tovaristva ímení T.Shevchenka u L'voví.

Dyba, YU. ta Ryazanova, N., 2019. Yahorlyk is a fortified town on the border of three states. Current Issues in Research, Conservation and Restoration of Historic Fortifications, 11. Chełm,Lviv: Rastr-7.

Dobrolyub'kiy, A. and Smirnov, Í., 2011. Nomads of southwestern Ukraine in the $10^{\text {th }}-17^{\text {th }}$ centuries. Kï̈v, Mikolaïv: Ílíon.

Kachor, L., 2009. Medieval Lviv. Fortifications. L'vív: Apríorí.

Kisílevs'kiy, V., 1966, Description of the Right Bank of Ukraine in the Atlas of Joannes Jansoni. Ukraïns'kiy istorik, 3, pp.3-4.

Kolesnikov, K.M., 2019. History of customs activity: Ukraine in international customs and trade networks. Tutorial. Dnípro: UMSF.

Kravtsov, S.R., 1993. Principles of regular urban planning of Galicia of the XIV - XVII centuries. PhD. Moskva.

Kravchenko, V., 2005. Lithuanian Metrics. - Book 561: Revisions of Ukrainian castles in 1545. Kiïv: Naukove tovaristvo ím. Shevchenka v Ameritsí, Naukove tovaristvo ím. Shevchenka v Ukraïní, NAN Ukraïni, Ínstitut ukraïns'koï arkheografïi ta dzhereloznavstva ím. M. S. Grushevs'kogo.

Krikun, M., 2008. Bratslav Voivodeship in the $16^{\text {th }}-18^{\text {th }}$ centuries: Articles and materials. L'vív: Vidavnitstvo Ukraïns'kogo Katolits'kogo Uníversitetu.

Kuchera, M. P., 1965. Medieval settlement near the village of Sokilci on the Southern Bug. Arkheologíya, 19, pp.201-214.

Logvin, G. N., 1959b. Castle in Ostroh. Kiïv: Derzhbudvidav.

Logvin, H. N., 1967a, Medzhibozh Castle: an architectural monument of the 16th century, t.1, pp.149-158.

Logvyn, H. N., 1967b. Lutsk Castle. Culture and art of ancient Rus'. Lenynhrad: Yzdatel'stvo Lenynhradskoho hosudarstvennoho unyversyteta, pp.102-107.

Logvyn, H. N., 1967c. Khotyn: castle. Kyiv: Mystetstvo.

Lukoms'ka, Z. V., 2007. Development of the planning and compositional structure of the center of Ivano-Frankivsk in the $17^{\text {th }}-20^{\text {th }}$ centuries. L'viv: Natsional'nyy un-t "L'vivs'ka politekhnika".

Lukoms'ka, Z. and Malyshko, O., 2015, Urban heritage of Kalush in the period of XV - XVIII centuries. Suchasni problemy doslidzhennya, restavratsiyi ta zberezhennya kul'turnoyi 
spadshchyny: Zb. nauk. pr. z mystetstvoznav., arkhitekturoznavstva i kul'turolohiyi, 11. Kyiv: In-t problem suchas. mystets. NAM Ukrayiny, Feniks, pp.183-188.

Mal'chenko, O., 2001. Fortified settlements of Bratslav, Kyiv and Podil voivodships (XVmiddle of XVII centuries). Kyiv: Instytut ukrayins'koyi arkheohrafiyi ta dzhereloznavstva im. M. Hrushevs'koho NAN Ukrayiny

Matsyuk, O. YA., 2005. Castles and Fortesses of Western Ukraine: historical travels. L'viv: Tsentr Yevropy.

Mykhaylovs'kyy, V., 2002. Castles on the sand. Review by: Oleg Malchenko. Fortified settlements of Bratslav, Kyiv and Podil voivodships (15 th - middle of $17^{\text {th }}$ centuries). Kyiv: Instytut ukrayins'koyi arkheohrafiyi ta dzhereloznavstva NANU.

Mohytych, R., 1993. Lviv is a fortress city. Viche, 15,16. L'viv.

Mohytych, R., 2008. Suburban fortifications of Lviv. Visnyk UZPR, 18. L'viv, pp.106-116.

Nahnybda, R., 2018. Church annals of the Baltic district of the Podolsk province 1866-1899. Drohobych : Kolo.

Nahnybida, R., 2011, Defensive fortifications of cities and towns of the Podolsk region of the $13^{\text {th }}-18^{\text {th }}$ centuries.. In: Pohorilets', O., red., 2011. Naukovyy visnyk «Mezhybizh»: Materialy chetvertoyi naukovo-krayeznavchoyi konferentsiyi «Starodavniy Medzhybizh v istoryko-kul'turniy spadshchyni Ukrayiny». Medzhybizh-Khmel'nyts'kyy: PP Mel'nyk A.A.

Nel'hovskyy YU. P., 1979, Some features of the castles of the Podolsk lands of Ukraine $16^{\text {th }}$ - early $17^{\text {th }}$ centuries. Arkhytekturnoe nasledstvo, 27. Moskva: Stroyyzdat, pp.89-96.

Novgorod first chronicle of senior and junior derivations, 1950. Moskva-Lenynhrad, pp.475477

Okonchenko, O., 2012. The meaning of the term "castle" in the study of the defense architecture of the Commonwealth. II Vseukrayins'ka naukovo-praktychna konferentsiya Kam"yanets'-Podil's'koho derzhavnoho istorychnoho muzeyu-zapovidnyka.

Olyanchyn, D., 1937. Description of the trip of the Swedish ambassador to Ukraine 16561657. Zapysky Naukovoho Tovarystva im. Shevchenka, 154, pp.51-52.

Otamanovs'kyy, V. D., 1993. Vinnytsia in the $14^{\text {th }}-17^{\text {th }}$ centuries. Vinnytsya: Kontynentprym.

Monuments of history and culture of the Vinnytsia region, 1990. Materyaly $\mathrm{k}$ svodu pamyatnykov ystoryy y kul'tury narodov SSSR po Ukraynskoy SSR, 8. Kyev.

Rybchyns'kyy. O.V., 2017. Formation and revitalization of historical cities of Ukraine. Doktor nauk. L'viv: Natsional'nyy universytet «L'vivs'ka politekhnika»

Rychkov, P.A., 2016. Notes on the urban history of Bratslav. In: Vinnyts'kyy oblasnyy krayeznavchyy muzey, 2016. Mista i mistechka Podillya vid doby Seredn'ovichchya do pochatku XX st. Materialy naukovoyi konferentsiyi 24-25 veresnya 2015 r. Vinnytsya, pp.314-323.

Rusov, A. A., 1876. Russian tracts in the late $17^{\text {th }}$ and early $18^{\text {th }}$ centuries. Kyev.

Ters'kyy, S.V., 2006. Luchesk in $10^{\text {th }}-15^{\text {th }}$ centuries. L'viv: Vydavnytstvo Natsional'noho universytetu 'L'vivs'ka politekhnika".

Tychuk, Y.E., 2016. The system of defense of the Grand Duchy of Lithuania from the Tatar threat as a reason for the emergence of cities in eastern Podillya. In: Vinnyts'kyy oblasnyy krayeznavchyy muzey, 2016. Mista i mistechka Podillya vid doby Seredn'ovichchya do pochatku XX st. Vynnytsya, pp. 44-48.

Fedunkiv, Z. B., 2015. Localization of the castle and city fortifications of Kalush in the $16^{\text {th }}$ $18^{\text {th }}$ centuries. on historical and cartographic materials. Pratsi Tsentru pam'yatkoznavstva, 27, pp.278-290. 
Filipova, H. V., 2016. Fortification of Kiev on the eve of the Great Northern War: the project of Lamot de Champier. Pytannya istoriyi nauky i tekhniky, 3, pp.12-18.

${ }^{1}$ Illia Lytvynchuk, ${ }^{2}$ Oleh Rybchynskii,

${ }^{1}$ PhD student email: illia.v.lytvynchuk@1pnu.ua

ORCID: 0000-0002-4635-060X

${ }^{2}$ professor

email: zoroleh@gmail.com

ORCID: 0000-0001-9936-6122

Arhitecture and Conservation Department, Institute of Architecture and Design National University "Lviv Polytechnick"

\section{PROBLEMS OF RESEARCH OF URBAN DEFENSE COMPLEXES OF CITIES OF THE EASTERN PODOLIA IN THE $16^{\text {th }}-18^{\text {th }}$ CENTURIES.}

(C) Lytvynchuk I., Rybchynskii O., 2020

In this article the authors touch on the methods of fortifications of the cities of Eastern Podillya - the least studied region of Ukraine. Components of long-term urban fortifications are considered as a single system of so-called urban defense complexes. Mandatory components of this system are a defensive castle and fortifications of the middletowns, which are recorded on the maps of military cartographers of the $17^{\text {th }}-18^{\text {th }}$ centuries. With this in mind, the authors clarify in the article the strategic importance of Eastern Podillya for the state and consider the development of urban defense complexes on its territory in retrospect. The analyzed sources allow us to speak about two periods of fortification development in Eastern Podillya. The first concerns the subordination of the territory to the Grand Duchy of Lithuania during the reign of Vytautas I, who expanded to the Black Sea coast and fortified the Southern Bug basin with a chain of fortifications and customs. After the Ottoman conquest of Constantinople and Crimea, trade ties with the south were lost, and its territory became dangerous for Podillya due to raids by nomads. Lithuania lost Vytautas' southern conquests and became completely dependent on Poland as a result of the introduction of a personal union. Subsequently, an administrative and political system identical to other provinces of Poland was introduced on the territory of Eastern Podillya and the Bratslav Voivodeship was formed. After the Union of Lublin, the territory of Bratslav became a source of huge lands for private ownership of magnates, who built their own systems for fortification of their estates, so the state was directly removed from strategic planning of defense of Eastern Podillya, royal power was concentrated only in the main capitals of Vinnytsia and Bratslav. On the basis of field surveys of partially preserved urban defense complexes, the article identifies the main types depending on the compositional and planning features. The location of fortifications on the terrain was also analyzed with the help of Google Earth software capabilities. Comparison of the data of 
relief cross-sections with the verified data of the foundation of fortified settlements revealed a stable correlation. Thus, the fortifications of the cities that were founded in the first period (Grand Duchy) were located on the heights of capes, ridges, hills, while the fortifications of the later ones were located in the valley. Given the low level of research of Ukrainian cities for the analysis of their defense systems, the authors recommend in further studies to investigate in detail the groups of cities that formed the estate complexes of specific magnate families in Podolia - Kalinov, Zbarazh, Zamoysk, and others for a unified defense system. and highlighting the characteristics of the spatial planning composition.

Key words: Eastern Podillya, Bratslav Voivodeship, urban defense complexes, castles, middletown fortifications, suburban fortifications. 